\title{
A comparison of male and female learners' English collocation learning through using WhatsApp
}

Ashiyan, Zahra

English Department, Faculty of Humanities, Najafabad Branch, Islamic Azad University, Najafabad, Isfahan, Iran(zahra_ashiyan@yahoo.com)

Salehi, Hadi $\bowtie$

English Department, Faculty of Humanities, Najafabad Branch, Islamic Azad University, Najafabad, Isfahan, Iran (Hadisalehi1358@yahoo.com)

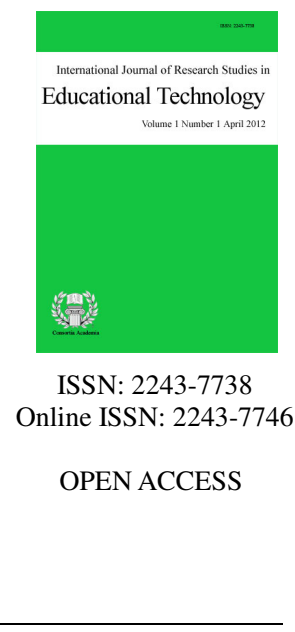

Received: 23 August 2016
Available Online: 20 October 2016

Revised: 3 October 2016 DOI: $10.5861 /$ ijrset.2016.1615

Accepted: 19 October 2016

\section{Abstract}

WhatsApp is a smartphone application for instant messaging and its unique feature is the ability to enhance communication, promote the social atmosphere, stimulate sharing among students, and act as a learning platform. The present study attempts to compare male and female students' English collocation learning who utilized WhatsApp as a mobile application in learning them. Thus, to access the focused objective, Oxford Placement Test (OPT) was conducted to both male and female in a language institute. Therefore, after administrating the mentioned test, a sample of 60 male and female EFL learners was selected. Hence, the selective participants were judged as intermediate learners in the test. In order to check the reliability of the collocation pretest, the test was pilot studied on 15 learners. Then, the two genders of participants in experimental group were suggested to use WhatsApp in order to practice and repeat the collocations. However, the male and female participants in control group received collocations instruction through the conventional method. After treatment, both groups were examined by a posttest. Accordingly, the findings showed that WhatsApp was an effective way for improving collocation learning regardless of gender and that using WhatsApp to acquisition of collocations is not gender specific. This enquiry also has prepared pedagogical implications for using WhatsApp as an ICT tool in learning a second language.

Keywords: mobile application; WhatsApp; collocations; Information and Communication Technology (ICT); Iranian EFL learners; Social Networking Sites (SNSs) 


\section{A comparison of male and female learners' English collocation learning through using WhatsApp}

\section{Introduction}

One of the most widely discussed subjects in the area of education is the use of ICT in English as a second language (ESL) teaching and learning (Yunus \& Salehi, 2012). There is no confusion that employing ICT in education upgrade teacher's pedagogical affair and promote students' learning exercise. Therefore, a group of ICT investigators assert that applying ICT moves forward education and prepares more teaching and learning supports for both the teachers and students (see Westera \& Sloep, 2001; Young, 2003; Salehi \& Salehi, 2012; Yunus, Salehi \& Chenzi, 2012). In fact since there have been humans, they have seeking for procedures to connect, network and promote with one another. Hence, the concepts behind "social networking" are not anything new in the digital age. It is necessary to human beings be aware of them. Because todays relationships are often started and developed on WhatsApp, Facebook, LinkedIn and Google+ (Milanovic, 2015).

One of the most swiftly technology in the society is the cell phone with more than six billion subscribers (UN Report: 2013). Prensky (2001) acknowledged that a cell phone or cellular phone as a mobile phone is a tool that can build and receive telephone calls over a radio link while moving around a wide geographical area. Recently, mobile learning is a multidisciplinary field of exploration that uses mobile gadgets for conversation, collaboration and instruction (William Stowe, 2013). Hence, the use of mobile learning activities in online learning and teaching courses is an advanced training technology in higher education (Army, 2014).

WhatsApp has become the "communication portal" for social networking that has quickly changed the way people communicate (Susilo, 2014). It is one of the evolutions which have been frequently used on particular mobile phones and computers (Yeboah \& Ewur, 2014). WhatsApp allows its users to send free text messages to each that is; users are not charged for a text sent through WhatsApp (Hindu, 2011). This is because WhatsApp sends messages through an internet data connection. It should be mentioned that many other, different message types, from simple text to pictures to audio files and videos as well as one's location using integrated mapping features are supported by WhatsApp (Alsaleem, 2014). This innovative technological achievement has led smartphones to be most favored by modern education experts at the end of 20th century and in the beginning of 21 th century.

On the basis, the prime purpose in the present paper will be to explore the impact of mobile phone applications (WhatsApp application) on learning collocations by male and female Iranian EFL learners. Making a pertinent statement about the significance of vocabulary, Krashen (1989) mentioned that the L2 learners understand the importance of vocabulary for mastering the L2 as they carry dictionaries with them rather than grammatical references. Those L2 learners who benefit from a rich knowledge of vocabulary perform better in both receptive and productive skills more successfully than those whose repertoire is smaller. It is argued that EFL learners need to achieve a threshold level of L2 vocabulary to be able to communicate fluently in L2 and understand an authentic text (Laufer \& Ravenhorst-Kalovski, 2010). According to Kim (2011), the EFL teachers are EFL learners in performing this task. Therefore, using an effective approach in promoting L2 vocabulary knowledge is one of the concerning of aware of the difficulty of mastering a number of L2 vocabulary, but may not know how effectively assist L2 educators.

Collocations are one of the hardest aspects of foreign and second language to acquire. Lewis (1997) defines collocation as "the readily observable phenomenon whereby certain words co-occur in natural text with greater than random frequency" (p. 8). In another definition collocation is "an expression consisting of two or more words that correspond to some conventional way of saying things" (Shokouhi \& Mirsalary, 2010). Lewis (2000) has prepared a practical and pedagogical perspective of collocation which is accepted from the point of view of 
learners. He proposed that "collocations are classes of words that students will not imagine to find together" (p. 29). Hyland (2008) points to collocation learning that is a key factor in second language learning and it refers to multi-word expressions as a main component of fluent linguistic production. Hill (1999) claims "students with good ideas often lose marks since they do not know the four or five most essential collocates of a key word that is primary to what they are writing about" (p. 5). Smith (2005) stated collocation should be included in the curriculum.

It may be of benefit to researchers and teachers who are willing to conduct a similar study in the future. It is also hoped that teachers who find it difficult to encourage their students to study outside the classroom and students who are willing to take control and manage their own learning can make use of this study. With the knowledge gained from this study, it will be possible for L2 educators, researchers, and curriculum and instructional technology planners to gain insight into how we can facilitate teaching English language collocations through social networking. Developing active language learning environments is a key element for the support of L2 learners, especially for Iranian EFL learners who have difficulty satisfying their language acquisition needs within the limited class hours during their language learning years. To meet this need, social networks in general and mobile applications in particular can be integrated into the L2 curriculum purposefully and appropriately, in order to promote learning communities where learners can participate on a regular basis.

\section{Literature Review}

In the period of modernization, the knowledge advancing years is typified by challenge and change. In fact, by the controversial impact of technology, human beings have plenty of challenges in this competitive arena. It is necessary that individuals should adapt themselves the changes by increasing capacity to know and perform things to acquiring quality (Yunus, Nordin, Salehi, Embi, \& Mahamod, 2013). Aksal acknowledged (2009) that, "technology links people around, the globe is pulled together." The way we communicate and work have transformed by technology (Sweeny, 2010). Unwin (2007) believed that over the last 15 years, there has been a phenomenal growth in ICT in all aspects of society. Then, education is not an exception and it has challenged and changed by the function of ICT. Majority of research analyses have recommended that the integration of ICT can advance academic action, reinforce motivation, and foster learning (Salehi; Shojaee \& Sattar, 2015). Curtin (2002) granted a definition of ICT as a sequence of activities that make the catching, saving, processing, shifting, and presenting of information simpler (Curtin, 2002). According to the United Nations Scientific, Educational and Cultural Organization (UNESCO) that defined ICT as the activity of placing the computer, telecommunication, and media technologies altogether (UNESCO).

The conception of ICT in education includes systems that empower information collecting, administration, operation, access and relations in different features (Ministry of Education, 2003). Oh and French (2004) claimed that new studies on this technology blending into education propose that pre-service teachers should accurately employ computer technology for teaching and learning. They perceived that the students were sufficiently prepared to implement technology in their teaching and learning practice, as they discerned that they had the main expertise and notion to apply computers and could operate technology intensified curriculum to contribute higher students' imagining skills and innovation. Higher educational investigation and exercise proved that contrasting approaches of integrating computer technology and the situation in which computers are worked, have transformed the impacts on student acquisition (Oh \& French, 2004).

Keegan's research confirmed that 'the impact of new technologies on distance learning students' has approved. Because people usually concurred that using technology in higher levels of education is determined for all students in general (Keegan, 2008). Majority of the participants in the study verified that using ICT can take care of learning and teaching. So that distant education can be facilitated for students to have access to student administrative processes. Most of the attendance asserted that they were remarkably eager about using ICT so that they could transmit and catch information and be in contact with the trainee and 'share information and ideas with people from the team.' Other educators (Chou \& Liu, 2005; Schulz-Zander et al., 2002) have 
really stated that with the support of a web-based effective learning situation, distance learning is both practical and beneficial. Other researchers (Anja \& Ngwo, 2007) declared that knowledge, tools and methods which appoint technology, are definitely substantial in every available organization in the distance education study. In educational organizations like schools, colleges and universities for the teaching and learning processes whether to public or private sections, technology has brought many functions. Additionally, ICT course content incorporated into the Web could be a substitute for the Educational Institutions to give their courseware speeches. Hence, every endeavor should be made to fully-utilize ICT; otherwise, lectures should be canceled in a given scenario. Social networking has influenced all features of modern society specifically the educational realm (Mason \& Rennie, 2008).

One of the aspects of social networking is the facility to enable appointment between characters. In an educational setting, connection between a student and scholar is of indispensible importance and social networking may be capable of facilitating this engagement between human beings. Another matter that connects to social networking is the large number of technologies that can be worked but some of these technologies may be better adapted to an educational situation than the others (Leitch \& Warren, 2011). For example, the 21 most influential instruments and channels consist of Facebook, linked in and G+ in which connecting and learning occur significantly (Milanovic, 2015). Using the social learning theory which assumes people in society learn from each other, the 32 Thai university students joined the Facebook. The participants' writing assignments on Facebook was collected. The analysis of data revealed that the use of Facebook in the teaching and learning of writing English has to a certain extent been effective. It needs to do more research to find ways to make it more effective thought.

One of the most swiftly technology in the society is the cell phone with more than six billion subscribers (UN Report, 2013). Prensky (2001) acknowledged that a cell phone or cellular phone as a mobile phone is a tool that can build and receive telephone calls over a radio link while moving around a wide geographical area. These devices are learners' habitual, daily means which are changing their first selection for entrancing the internet and making usage of communication services (Lundin et al., 2010; Melton \& Kendal, 2012). Recently, mobile learning is a multidisciplinary field of exploration that uses mobile gadgets for conversation, collaboration and instruction (Stowe, 2013). Hence, the use of mobile learning activities in online learning and teaching courses is an advanced training technology in higher education (Army, 2014).

McNeal and Hooft (2006) believed that cell phones as principal facilities that create training are more relevant and significant to enhancing students scholarly and numeracy skills. Traxler (2007) found that a structure of multiple literary which prepares a bridge between the real life texts of the society and formal learning thereby establishing a multimodal academic tactic to learning. Mobile learning technology is a modern revolution of remote learning. Researchers regard that the M-learning mode was selected by distance instruction teachers and is connected to the learning procedure operated by online tutor (Blehch, 2014).

The mobile appliances equip learners with the opportunity to learn in different contexts and time (Crescente \& Lee, 2011). Mobile gadgets are applied at higher educational institutions like universities to develop online connections through exchange of views and to share knowledge between students by mobile communication modes such as instant messaging; Mobile Social Networks and Web based learning (Echeverria, Nussbaum, Calderon, Bravo, \& Infante, 2011). The mobile devises such as iPads, iPods, tablets, Mp3 players mobile phones and so on are used in mobile learning technologies. The mobile devices provide mobility and interactivity for students (Trentin \& Repetto, 2013). Smart phones are not instructors by themselves; rather, they are instructional tools which have internet access, voice and text messaging, and voice recording. For the sake of learning a new language successfully, relatively the whole package of these characteristics can enable language learners to practice their communicative skills, benefiting from the privilege of genuine content, and task accomplishment. In the realms of research these worthwhile benefits are very rare, or in other words it is an optimal situation that can hardly be found (Traxler, 2007). 
WhatsApp has become the "communication portal" for social networking that has quickly changed the way people communicate (Susilo, 2014). It is one of the evolutions which have been frequently used on particular mobile phones and computers (Yeboah \& Ewur, 2014). As an exclusive, cross-platform instant messaging subscription service which is available on the new generation of smart phones such as IPhone, Android, Blackberry, and Nokia mobile phones, WhatsApp allows its users to send free text messages to each that is, users are not charged for a text sent through WhatsApp (Hindu, 2011).This is because WhatsApp sends messages through an internet data connection. It should be mentioned that many other, different message types, from simple text to pictures to audio files and videos as well as one's location using integrated mapping features are supported by WhatsApp (Alsaleem, 2014). With social networks rapidly gaining prominence in this scenario, WhatsApp is emerging as a tool that can be used for different educational purposes. WhatsApp is already being used to teach vocabulary or to disseminate general information and links for language learning.

Technologies such as WhatsApp messages have achieved increasing prevalence in societies. These kinds of messaging technologies are greatly applied among undergraduate learners nowadays (Lenhart, 2007). Digital dialogues between members of students and trainers have become common during the past decade through different channels: SMS, Email, Facebook groups, Twitter and freshly WhatsApp. Every one of these tools has various attributes that affect suitability for learning goals (Calvo, Arbiol, \& Iglesias, 2014). One of the most exciting issues about WhatsApp messaging and other general technologies (text messaging, video games, etc.) is that they are prospective acquisition tools (Dearstyne, 2011; Brown-Owens, Eason, \& Lader, 2003). Unlike the other forms communication and any other technologies that occasionally do not work and students do not use after school hours, WhatsApp enables easy and quick transference of links to study materials. Sending homework materials through WhatsApp make sure that all students receive the message, whether it is a video specified for class or copy of an answer to an exercise sent outside the classroom hours (Bouhnik \& Deshen, 2014).

While majority of educationalists acknowledge that WhatsApp messages are vastly worked by undergraduate learners, there sound to be one separate idea of its impact on student academy (Alsaleem, 2014). There are individuals who consider the use of so-called "Internet English" not only as an example of how language is continuously progressing and shifting, but also as a kind of literacy, which can be developed to appoint learners in more customary learning. Now, people are really watching words on phone screens. According to Helderman (2003) and Linhart (2007), instant messaging and e-mail are a new generation of writers, accustomed to translating their views and feeling into words. They write more than any individual has since the days when telephone calls were limited (Alsaleem, 2014). Overall, according to Bere and Chipunza (2013) WhatsApp has turned into a shared platform which promotes accessibility, motivates cooperation and strengthens motivation to take a lively component in academic assignments.

Collocations can be defined in different procedures but the most usual definition of collocations is the trend of one word to happen with one or more other words in a fossilized or completely fossilized combination (Ashouri, Arjmandi, \& Rahimi, 2014). Cruse (1986), defines collocations as "sequences of lexical items which habitually co-occur, but which are nonetheless fully transparent in the sense that each lexical constituent is also a semantic constituent" (p. 40). As another definition, collocations refer to "the way in which words are used together regularly" (Richards \& Schmidt, 2002, p. 87). According to the definition, collocation refer to the constraints on how words can be utilized together; for instance, which verbs and nouns come together, or which adjectives are applied with specific nouns. For example, in English the verb do collocates with damage, duty and wrong, but not with trouble, noise and excuse. Similarly, good collocates with chance but not with probability. We say a good chance but high probability. As a result most of the linguists paraphrases of Firth's (1957, p. 183) definition that collocations are "words in habitual company".

The work of Firth had an impact on many linguists who studied collocations. Among these studies, Sinclair (1991) has introduced new concepts "the idiom principle" and "the open-choice principle" which are the two principles that govern the choice of words by speakers and writers. The first principle results in collocations or 
other degrees of idiomaticity like for instance idioms or fixed phrases in contrast to the second principle which is more general and includes a wide range of possible and acceptable words. Hoey (2004) asserted that a collocation is the association of a word with a particular set of meanings. It means that rather than the words, meanings constitute a collocation. That is what makes a word collocates with specific meanings rather than others. He illustrated his view with the example of the word chilly. Within the prosody of "time", chilly collocates with morning, night, evening, day; whereas it does not collocate with minutes or decades.

The learners and their trainers unconsciously ignore learning collocations and own incomplete English learning. It means that the students are not capable to be fluent through the several intensive courses (Motallebzadeh, Beh-Afarin, \& Rad, 2011). The researchers in different studies believed that SMS can assist to enlarge learners' opportunities in significant ways and supply better conditions for learning collocations. The quick advancements in ICT have generated modern procedures to develop the access and quality of study. Mobile phones are current addition to the ICT for learning a language (Motallebzadeh, Beh-Afarin, \& Rad, 2011). Cavus and Ibrahim (2009) declared, "There is an increasing use of wireless technologies in education all over the world. On balance, wireless technologies such as laptop, computers and mobile phones reorganize education and alter the traditional classroom according to learning and teaching into anytime and anywhere education." Todays mobile devices are represented as offering modern learning capabilities which manifest a dynamic transformation in the strategies applied by learners and their production and use of learning products (Conole et al., 2008). The immediacy and portability of mobile phones permit students to learn in their selected time and place (McNicol, 2004). As Anoshina pointed out (2005), SMS refers to the usage of technology for acquiring in an expansive sense and involve educational processes performed with different theoretical models and use of different educational methods and is according to activities that happen via any kind of electronic gadget.

As there are two hours per week for the English learning in majority of schools and universities, then the English class changes into the only time to utility of English and learners encounter to the challenge of absence exposure to English. Teachers should consider how to use limited time to enhance language learning and there is a serious requirement for them to apply an effective independent approach for learners to develop and enlarge their collocations size. They also should make learners conscious of collocations and persuade them to save collocations in their memory by fresh techniques and advanced technologies (Motallebzadeh, Beh-Afarin, \& Rad, 2011).

According to Grace (1998, p. 8) who asserts that, "because of class time restriction and the importance of collocations, most of the investigation and strengthening is the duty of students outside the context of classroom." Collocations are acknowledged "several learning activities can be delivered to students simply and immediately via SMS technology." Besides, the findings have showed that students have positive comprehension about the implementation of mobile phones as a learning device (Motallebzadeh, Beh-Afarin, \& Rad, 2011). Savil-Smith and Kent (2003) investigated that using mobile for learning can increase student's motivation, reinforce be responsible, support organizational expertise, do as reference instruments, and aid students' advancement and evaluation. Finally, it has been cited previously that collocations do not receive enough attention in Iran; therefore, Motallebzadeh, Beh-Afarin, and Rad (2011) used short message service to help Iranian Intermediate EFL learners to retain English collocations. The learners had positive attitudes towards learning collocations via SMS.

Recently, the issue of acquisition collocations has changed to an extreme priority in language teaching (Alfahadi et al., 2014). In reality, one of the most essential parts of knowing a word is to have a powerful collection of collocations. It looks that utility of collocations is an indication of native writing and speaking which prompts to fluency in language usage. On the other hand, learning collocations also reduces learners' challenge when reading and listening. In Iran, almost the unique place of learning and practicing English, particularly acquiring English lexicons is the English language classrooms where English is a foreign and not a second language. According to Derakhshan and Khodabakhshzadeh (2011) restricted time in classes has been 
A comparison of male and female learners' English collocation learning through using WhatsApp

caused teachers do not have enough time to thoroughly cover and practice all dimensions of vocabulary learning, including collocations.

The rapid progress in technology has generated modern chances to strengthen the effectiveness and quality of training in total, and language acquiring in particular. In many constructions of e-learning, learning through utilizing email is an idea in education which has not been applied much in instruction and acquisition of collocations (Mark, 1995). Hence, email is considered as one of the heated topics in college English teaching and learning. The collocation knowledge of learners may be improved by using out-of-class instructions such as email. In CALL procedure the effect of in- class paper and pencil training with the out of class email instruction in developing English collocations are compared. The results showed that out of class email instruction is a more effective tool in improving students' collocation knowledge (Solgi \& Tafazoli, 2014).

Collocations are scarcely learned and experienced and occasionally ignored in language classes in Iran. The fact is that just the minor percent of learners regard collocations. Because the learners and their trainers unconsciously ignore learning them; therefore, incomplete English learning means that the students are not capable to be fluent through the several intensive courses (Motallebzadeh, Beh-Afarin, \& Rad, 2011). So, according to Thoornton and Houser (2005), mobile phones improve continual enquiry which causes to more encounter with the lessons. Their findings revealed that constant practice has a more impact on memory and learning. Moura and Carvaho (2010) acknowledged "several learning activities can be delivered to the students easily and immediately via SMS technology."

\subsection{A Comparison of the Previous Literature Review with the Study}

Digital dialogues between members of students and trainers have become common during the past decade through different channels: SMS, Email, Facebook groups, Twitter and freshly WhatsApp. Every one of these tools has various attributes that affect suitability for learning goals (Calvo, Arbiol, \& Iglesias, 2014). One of the most exciting issues about WhatsApp messaging and other general technologies (text messaging, video games, etc.) is that they are prospective acquisition tools (Brown-Owens, Eason, \& Lader, 2003; Dearstyne, 2010). Unlike the other forms communication and any other technologies that occasionally do not work and students do not use after school hours, WhatsApp enables easy and quick transference of links to study materials. Sending homework materials through WhatsApp make sure that all students receive the message, whether it is a video specified for class or copy of an answer to an exercise sent outside the classroom hours (Bouhnik \& Deshen, 2014).

While majority of educationalists acknowledge that WhatsApp messages are vastly worked by undergraduate learners, there sound to be one separate idea of its impact on student academy (Alsaleem, 2013). There are individuals who consider the use of so-called "Internet English" not only as an example of how language is continuously progressing and shifting, but also as a kind of literacy, which can be developed to appoint learners in more customary learning. Now, people are really watching words on phone screens. According to Helderman (2003) and Lenhart et al. (2009) instant messaging and e-mail are a new generation of writers, accustomed to translating their views and feeling into words. They write more than any individual has since the days when telephone calls were limited (Alsaleem, 2013). Overall, according to Bere and Chipunza (2013) WhatsApp has turned into a shared platform which promotes accessibility, motivates cooperation and strengthens motivation to take a lively component in academic assignments.

The rapid progress in technology has generated modern chances to strengthen the effectiveness and quality of training in total, and language acquiring in particular. In many constructions of e-learning, learning through utilizing email is an idea in education which has not been applied much in instruction and acquisition of collocations (Mark, 1995). Hence, email is considered as one of the heated topics in college English teaching and learning. The collocation knowledge of learners may be improved by using out-of-class instructions such as email. In CALL procedure the effect of in- class paper and pencil training with the out of class email instruction 
Ashiyan, Z., \& Salehi, H.

in developing English collocations are compared. The results showed that out of class email instruction is a more effective tool in improving students' collocation knowledge (Solgi \& Dara, 2014).

Collocations are scarcely learned and experienced and occasionally ignored in language classes in Iran. The fact is that just the minor percent of learners regard collocations. Because the learners and their trainers unconsciously ignore learning them; therefore, incomplete English learning means that the students are not capable to be fluent through the several intensive courses (Motallebzadeh, Beh-Afarin, \& Rad, 2011). So, according to Thoornton and Houser (2005), mobile phones improve continual enquiry which causes to more encounter with the lessons. Their findings revealed that constant practice has a more impact on memory and learning. Moura and Carvalho (2010) acknowledged "several learning activities can be delivered to the students easily and immediately via SMS technology."

\section{Methodology}

\subsection{Participants}

To pile up the required data, a sample of 60 Iranian EFL learners, aged 20 to 28, from Kimiya Institute located in the city of Masjidsoleyman, Iran were selected. These participants were selected from 80 individuals who sat for the Oxford Placement Test (OPT). Sixty learners received the required score in OPT. Regarding their educational background; the majority of the participants had university degree, B.A. in majors other than English from state or Azad universities all around Iran. Furthermore, a few of the learners were not students at college. They had no certification of college. They had studied in high school and had diploma. All the selected individuals were native speakers of Persian and their level of English language proficiency was intermediate. The participants were divided into two groups: experimental and control groups. In addition, 15 learners took part in the pilot-testing of the instruments. They were also native speakers of Persian and their level of English language proficiency was intermediate. They had been selected based on their performance on Oxford Placement Test (OPT).

\subsection{Instruments}

The participants in this study were given the following tests for data collection. All of the selected learners participated in the following examinations.

Oxford Placement Test (OPT) - For conducting this research, the researcher needed an OPT which is a standard examination, to determine the level of the students. The whole population in the present examination was 80 EFL learners. Then the individuals whose their scores were 70 and the higher, were chosen. The selected learners were regarded as the sample for experimental and control groups. The OPT was carried out to participants studying English as a foreign language in a language institute. The OPT consisted of 60 items, including 10 multiple-choice and true-false reading, 10 writing, and 40 multiple-choice language use items. The time limit for answering the test was 65 minutes. This study used all parts of the OPT to select a group of intermediate level L2 students and to figure out L2 reading proficiency level of the students. Therefore, the participants answered the structure, vocabulary, writing and reading comprehension segments of the test. After administrating the test, the received results were evaluated based on the OPT associated rating levels chart and those who obtained 70 or more in this test were judged as intermediate learners.

Pretest and posttest - The participants in this study were given two tests. Then a 30-item collocation test was given to the learners before and after the treatments of study as pretest and posttest. This test was syllabus-based and was used to measure the learners' collocation knowledge. It consisted of multiple choice items, fill in the blank, matching and completion.

In order to check the reliability of the collocation pretest, which had been designed by the researcher, the 
test was pilot studied on 15 learners of the same age and proficiency level. The participants in pilot testing took part in the pretest separately. An experimental research design was employed by the researcher. The data collection procedure was carried out in a language institute. The first step of this study was the administration of OPT. The OPT was administrated to a group of learners $(\mathrm{N}=80)$ in order to choose intermediate EFL learners. The majority of the participants had university degree or they were students at college. Based on the OPT associated rating levels chart, the participants whose scores were 70 or more were regarded as the sample of the investigation. The selected individuals were divided into two groups: experimental and control. The selected participants in two groups took the pretest in order to evaluate their collocation knowledge.

Accordingly, both the experimental and control groups participated in the examination. The level of the two groups is evaluated by the same analysis. In order to evaluate the reliability of the tests, KR-21 formula was conducted. The results indicated that both pretest $(r=.81)$ and posttest $(r=.83)$ had good reliability. To make sure about the validity of the tests, three experts who had Ph.D. degrees in TEFL was consulted and they stated that the test had good validity.

\subsection{Procedure}

An experimental research design was employed by the researcher. The data collection procedure was carried out in a language institute. The first step of this study was the administration of OPT. The OPT was administrated to a group of learners $(\mathrm{N}=80)$ in order to choose intermediate EFL learners. The majority of the participants had university degree or they were students at college. Based on the OPT associated rating levels chart, the participants whose scores were 70 or more were regarded as the sample of the investigation. The selected individuals were divided into two groups: experimental and control. The selected participants in two groups took the pretest in order to evaluate their collocation knowledge. Accordingly, both the experimental and control groups participated in the examination. The level of the two groups is evaluated by the same analysis.

The participants in experimental group installed WhatsApp on their cell phones or tablets. The participants in the experimental and control groups were taught the coursebook Vocabulary in Use Basic (10 units) inside the classroom. Both groups repeated, practiced, and did the exercises in the book separately. Then, the experimental group used WhatsApp in order to practice and repeat the selected and taught collocations with native and non-native English speakers around the world outside of the L2 classroom. The participants in the experimental group were asked to keep the thread of their conversation by using Whatsapp application. Moreover, they were asked to report their progress after each session. They reported their progress through brief evaluation of collocation knowledge. The participants in the control group received collocation instruction through the conventional method which was popular in their courses. Therefore, the control group had no instrument for learning collocations. By the end of the course, the posttest was run to compare the differences in vocabulary learning improvement of two groups of participants which was run in 30 minutes.

\subsection{Data Analysis}

To access the focused objective, Oxford Placement Test (OPT) was conducted to both male and female in a language institute. Therefore, after administrating the mentioned test, a sample of 60 male and female EFL learners was selected. Hence, the selective participants were judged as intermediate learners in the test. In order to check the reliability of the collocation pretest, the test was pilot studied on 15 learners. Then, the two genders of participants in experimental group were suggested to use WhatsApp in order to practice and repeat the collocations. However, the male and female participants in control group received collocations instruction through the conventional method. After treatment, both groups were examined by a posttest.

After the essential data were collected, the Statistical Package for Social Sciences (SPSS, 20) was used in order to run required statistical tests. The researcher ran independent sample $t$ tests in order to verify the hypotheses. In addition, descriptive statistics (such as mean, standard deviation, kurtosis, skewness and 
Ashiyan, Z., \& Salehi, H.

frequency) were used to show the general information of obtained scores.

\section{Results}

In order to assess the effects of training among the groups of learners, the performance of the participants in experimental and control groups were to be compared to make sure that they were homogeneous at the beginning of the treatment. To this end, an OPT was administered and those participants who obtained a score of 70 or more were chosen as the participants of the study $(\mathrm{N}=60)$. Then, the groups were arranged in a way so as to the number of male and female learners were roughly equal. What follow is the detailed results gained in this study.

As it is shown in Table 1, there is no statistically significant difference between the mean scores of QEG and CG groups (the mean score for experimental group is 48.44 and that for control group is 48.84 that is a difference of 0.40 which is not a significant difference). In order to be more objective regarding the claim of homogeneity of the two groups, an independent sample t-test was run between the scores of OPT of control and experimental groups. Results show that the t-observed is -0.32 which is lower than the t-critical from the table of $\mathrm{t}$-scores, so it can safely be claimed that the two groups are homogeneous in terms of their proficiency level. As a result, the study went on safely with these two groups.

Table 1

Descriptive Statistics for the Mean Comparison of the OPT between $Q E G$ and $C G$

\begin{tabular}{lccccc}
\hline & Groups & $\mathrm{N}$ & Mean & $S D$ & Std. Error Mean \\
\hline VAR0000 & 1 & 30 & 48.44 & 5.18 & 0.99 \\
& 2 & 30 & 48.84 & 3.58 & 0.70 \\
\hline
\end{tabular}

Note. 1 = Quasi-experimental group, $\mathrm{QEG}$, or group A. 2 = Control group, $\mathrm{CG}$, or group B.

The research hypothesis of the study at hand stated that gender has no significant effect on learning collocations through electronic learning. In order to test this hypothesis and find the answer for the research question of the study, it was also required to insure that both the control and experimental groups were equivalent in terms of gender. To this end, the two groups of the study and their participants were arranged on the onset of the study using stratified random sampling to assure the same proportion regarding their gender. Table 2 illustrates the frequency distribution of the two groups.

Table 2

Frequency Distribution of Gender by Treatment Conditions

\begin{tabular}{lccccc}
\hline \multicolumn{1}{c}{ Treatments } & $\mathrm{N}$ & Males & $\%$ & Females & $\%$ \\
\hline WhatsApp & 30 & 16 & 26.66 & 14 & 23.33 \\
Traditional & 30 & 13 & 21.66 & 17 & 28.33 \\
Total & 60 & 29 & 48.32 & 31 & 51.66 \\
\hline
\end{tabular}

As shown in Table 3 below, posttest mean in experimental group for males is $X=21.06$ and for females equals $\mathrm{X}=17.28$. The same results for posttest means in control group for males and females are $\mathrm{X}=17.38$ and $\mathrm{X}=16$, respectively. So a difference in posttest means of both groups could be observed. But it is not clear yet whether the difference is significant or not.

The next step was then to run a one-way analysis of variance (ANOVA) on the results of the posttest to compare the achievements of both genders of both groups and to see whether the difference is statistically significant or not. Table 4 represents the results. Table 4 gives both between-groups and within-groups sums of squares, degrees of freedom, F value, etc. The significant value is smaller than $0.05(0.027<0.05)$, so there is a significant difference among the mean scores on the independent variable (posttest scores) for the four sub 
A comparison of male and female learners' English collocation learning through using WhatsApp

groups. As you can see, these results coincide with what we observe in means table further above (Table 3), where the mean tended to change with each group in the case of the posttest. It is difficult, however, at this point to tell if this significant difference occurred in males or females and whether the difference occurred in experimental or control groups since ANOVA provides information on whether or not these groups differ, but it provides no information as to the location or the source of the difference. Having received a statistically significant difference, we can now look at the results of the post-hoc tests provided in Table 5 to be able to locate the source of significance in our data.

Table 3

Means Comparison of Males and Females of Experimental and Control Groups

\begin{tabular}{|c|c|c|c|c|c|c|c|c|}
\hline \multirow{2}{*}{ Post test scores } & \multirow{2}{*}{$\mathrm{N}$} & \multirow{2}{*}{ Mean } & \multirow{2}{*}{$\mathrm{SD}$} & \multirow{2}{*}{ Std. Error } & \multicolumn{2}{|c|}{ 95\% Confidence Interval for Mean } & \multirow{2}{*}{ Min. } & \multirow{2}{*}{ Max. } \\
\hline & & & & & Lower Bound & Upper Bound & & \\
\hline experimental group males & 16 & 21.06 & 6.22 & 1.55 & 17.74 & 24.37 & 10.00 & 30.00 \\
\hline experimental group females & 14 & 17.28 & 5.18 & 1.38 & 14.29 & 20.27 & 6.00 & 25.00 \\
\hline control group males & 13 & 17.38 & 3.64 & 1.00 & 15.18 & 19.58 & 12.00 & 24.00 \\
\hline control group females & 17 & 16.00 & 3.69 & 0.89 & 14.10 & 17.89 & 9.00 & 21.00 \\
\hline Total & 60 & 17.95 & 5.10 & 0.65 & 16.63 & 19.26 & 6.00 & 30.00 \\
\hline
\end{tabular}

\section{Table 4}

One-way ANOVA on the Posttest of Males and Females of Experimental and Control Groups

\begin{tabular}{rccccc}
\hline \multicolumn{1}{c}{ Posttest scores } & Sum of Squares & df & Mean Square & F & Sig. \\
\hline Between Groups & 229.97 & 3 & 76.65 & 3.285 & 0.02 \\
Within Groups & 1306.87 & 56 & 23.33 & & \\
Total & 1536.85 & 59 & & & \\
\hline
\end{tabular}

As Table 5 shows, in column called 'mean differences', there are some asterisks next to the values listed. Asterisks show that the four groups being compared are significantly different from one another at $p<0.05$ level. The exact significant value is given in the column labeled sig. In the results presented above, sub-group 1 or males in experimental group which received instruction through WhatsApp, is significantly different from other sub-groups $(0.00<0.05)$. That is, males in experimental group outperformed females in experimental group and males and females in control group both receiving traditional method of collocation teaching.

According to the statistics depicted in Table 5, it is not the sole females QEG which defeated both sub-groups of $\mathrm{CG}$, but sub-group 2 winning the second place, has also reached a statistically significant difference from sub-groups 3 and $4(0.00<0.05)$. The significant value of females CG (group 3 ) and males CG (group 4 ) is more than $0.05(0.24>0.05)$, so they are not significantly different from one another at $p<0.05$ level.

These results show that even though males in experimental group performed better on posttest than all other groups, since the difference was not statistically significant comparing to that of males in both groups, we cannot reject the hypothesis. To put it in other words, we have to accept the null hypothesis expressing that gender has no significant effect on learning collocation through WhatsApp. That means that WhatsApp is an effective way for improving collocation learning regardless of gender and that using WhatsApp to learn collocation is not gender specific. 
Ashiyan, Z., \& Salehi, H.

Table 5

Results of Post-hoc Test

\begin{tabular}{lllll}
\hline \multicolumn{1}{c}{ (I) Groups } & \multicolumn{1}{c}{$(\mathrm{J})$ Groups } & $\begin{array}{c}\text { Mean Difference } \\
(\mathrm{I}-\mathrm{J})\end{array}$ & Std. Error & Sig. \\
\hline experimental group males & experimental group females & $3.77^{*}$ & 1.76 & 0.03 \\
& control group males & $3.67^{*}$ & 1.80 & 0.04 \\
& control group females & $5.06^{*}$ & 1.68 & 0.00 \\
experimental group & experimental group males & $-3.77^{*}$ & 1.76 & 0.03 \\
females & control group males & -0.09 & 1.86 & 0.95 \\
& control group females & 1.28 & 1.74 & 0.46 \\
control group males & experimental group males & $-3.67^{*}$ & 1.80 & 0.04 \\
& experimental group females & 0.09 & 1.86 & 0.95 \\
& control group females & 1.38 & 1.77 & 0.44 \\
control group females & experimental group males & $-5.06^{*}$ & 1.68 & 0.00 \\
& experimental group females & -1.28 & 1.74 & 0.46 \\
& control group males & -1.38 & 1.77 & 0.44 \\
\hline
\end{tabular}

Note. *The mean difference is significant at the 0.05 level.

\section{Discussion}

The research question of the study investigated whether the application of WhatsApp had any significant difference between males and females. The current study attempted to address the question that was: "Is there any significant difference between male and female Iranian EFL learners in using WhatsApp for learning collocation?" subsequently, the following null hypothesis was formulated and explored: "There is no significant difference between male and female Iranian EFL learners in using WhatsApp for learning collocations." Regarding the findings males in experimental group outperformed on the posttest but the difference was not statistically significant through comparing to that of males in both groups; accordingly, the researcher cannot reject the hypothesis. To put in other words, the examiner had to accept the null hypothesis expressing gender had no significant effect on learning collocation through WhatsApp. It was an effective way for improving collocation learning regardless of gender and that using WhatsApp to learn collocation is no gender specific.

The findings related to the research question seem to be compatible with the findings of Salavati (2016) who used instructional video games as an ICT tool for teaching English vocabularies to Iranian EFL learners. But this study stated that male and female language learners had the same progress and no significant difference was manifested. The findings of this study are also in line with the findings of Yahya Abadi (2015) who represented that utilization of Viber application in learning a second language has no relationship with gender. The findings of the study revealed that gender did not lead to any transformation in the performance of both experimental and control group learners; in other words, gender was shown to have no function in the enhancement of the acquisition of collocations of EFL learners. On the other hand, this finding run counters to the findings of Mazaji (2015) who investigated the effect of digital games on vocabulary acquisition of low proficiency Iranian male and female EFL learners. Thus, the findings of the cited study manifested that digital games can be significant for vocabulary learning among both male and female EFL learners.

\section{Conclusion}

In fact, in the modern and advanced age, cell phones are influential and substantial means of communication to the most of individuals. More recently, Yeung (2013) declared that social technologies such as WA and Viber 
go around language learning and communication. In particular, WhatsApp as one of the messaging applications has become popular among learners in various classroom settings that have allowed them to communicate with others in their contact list through text. Such great possibilities of WhatsApp tool have turned it into a magic resource for teaching lexicons of a second language to L2 learners.

After conducting different analyses, it was made clear that traditional learning and acquisition collocations through WhatsApp were not the same in learning since the group that received instruction via WhatsApp outperformed the other group that received traditional learning. Finally, the null hypothesis of no relationship between gender and using WhatsApp to teach collocations was confirmed since there was not such a significant difference to prove it wrong. In fact, it was displayed that gender contrasts had no function in the advancement of collocations of Iranian EFL learners. Therefore, gender must be considered as a neutral characteristic in the study at hand.

\subsection{Implications of the Use of Technology in Teaching}

The findings of this study declared that technology and education are closely related to each other in the information era and consequently technology has the potential ability to make learning easier and more exiting. Therefore, significance and implication of technology in learning a second language has been clarified. In fact, technology can permit learners of a second language to be connected to each other. When learners utilized digital tools to be connected, they were able to internalize content in order to learn. This connection and exchange of information can help learners develop the capability to create new knowledge at any point in time. The rapid progress of technology affected many changes both in knowledge generally and learning a language particularly. One of the marvelous transformation of learning acknowledged that learning is no individual activity, but rather a process that allowed the students to flourish in the digital era.

Furthermore, the study in hand aimed at investigating the key function of using MALL in EFL classes. The present study evaluated a combination of technology and language practice in acquisition of collocations of a second language. According to the findings of the study, Iranian EFL learners can discriminate the attributes and uses of MALL in learning a second language and apply its advantages and implications appropriately to their learning. On the other hand, this study suggested that an advancement of collocation knowledge through using MALL can guarantee the vocabulary repertoire of learners. The present study aimed at investigating the key function of using MALL in male and female EFL classes. It evaluated a combination of technology and language practice in acquisition of collocations of a second language. It is also hoped that the findings of this study and similar investigations can motivate EFL learners to benefit from such useful tools to boost their second language learning. Thus, EFL materials developers and syllabus designers should consider integrating ICT tools such as MALL in their materials.

The findings of this study suggest essential implications for learning a second language. Firstly, with the fast advancement of technology, learners should have basic knowledge of ICT tools like mobile-based means and its applications. They should be aware of the fact that technology and education are closely related to each other in the information era, hence; it can make learning easier and more exciting. Thus, the present study may reinforce learners of second language to improve their view about the nature and significance of ICT tools like mobile phones in learning. Secondly, through knowledge of how various online mobile phone applications are applied in different studies can help learners with varieties of resources to develop second language acquisition. Finally, the findings of this study can motivate both male and female EFL learners to use and benefit from these significant instruments to promote their knowledge of a second language more than before. Furthermore, it has been manifested that one main variation between EFL learners and learners in a second language context is that the earlier cannot profit from costly exposure to the target language. Nevertheless, ICT tools like WhatsApp can overcome this limitation and create more fine opportunities for EFL learners. 
According to the present study, WhatsApp as a learning platform used the groups in order to improve the accessibility of learning materials and the performance of learning activities. Consequently, four main factors that motivated the researcher for the creation of a WhatsApp group are mentioned in the following:

D By establishing a WhatsApp group, the students could communicate with their teacher and classmates, transmit data, and assist learners to feel freshly.

$>$ The researcher groomed a positive social atmosphere in order to build a feeling of belonging and community through WhatsApp groups.

$>$ The students were able to share information when started to help each other's questions. By creating a dialogue, the students worked as a team.

$>$ The WhatsApp teams apply the learning platform in order to increase the accessibility of learning materials and activities.

\subsection{Practical Implications}

The findings of this study can be beneficial to L2 pedagogy. The results of the present study will help L2 teachers make use of the mobile applications for providing authentic communicative situations for L2 learners. Moreover, the L2 teachers are able to detect the L2 learners' areas of weakness and strength and act accordingly. The L2 teachers should assist their students. Particularly, this study may pave the way for the L2 teachers to guide their students to raise their consciousness and awareness of their own learning towards the actual goals of language learning and help them proceed towards meaningful learning. Probable findings regarding the effectiveness of social networking sites and its prospected implication in developing collocations can pave the way for better communication in an L2 culture and society. The L2 learners knowing how to communicate with other L2 learners on social networking sites can try to do their best to improve their communicative competence

\subsection{Suggestions for Further Study}

This present investigation owns the potential studies that can offer definite suggestions for further research in future. In what follows, several suggestions may be made from this research for forthcoming research enquiries:

$>$ Another area of enquiries would be to study whether L2 teachers and learners regard new technology implementations and utilization in and outside of the language classrooms. It seems necessary to scrutinize various points of view among $\mathrm{L} 2$ teachers and learners.

$>$ Further investigations are needed to explore the impact of other ICT tools on vocabulary learning and collocations. As the present study focused on WhatsApp as an ICT tool. In fact, the additional surveys are necessary to investigate the consequences of the other social networks and ICT tools on learning and development a second language.

$>$ It seems mandatory to analyze whether a long-lasting time framework probably conduct to finer development of second language learning. In fact, it would appear a longer time can manage such treatments and advance EFL learners' knowledge.

> Supplementary investigations are required to examine whether online application may effect on language development. To sum up, researchers can evaluate classrooms with online learning to find out whether they have impact in learning English as a foreign language. In fact, the evaluation of online classrooms can be compared easily with conventional classrooms in which no tool is 
implemented in learning a second language.

> The present study uniquely considered collocations learning in second language. However, vocabulary owns some other different characteristics which are necessary to be considered for complete learning of a second language. The other important characteristics of vocabularies are parts of speech, proverbs, idioms and etymology. Moreover, it would be helpful to study the impacts of WhatsApp on learning four main skills and subskills such as grammar, pronunciation and the other areas of language development.

\section{References}

Aksal, F. A. (2009). Action plan on communication practices: Roles of tutors at EMU Distance Education Institute to overcome social barriers in constructing knowledge. TOJET: The Turkish Online Journal of Educational Technology, 8(2), 78-82.

Alfahadi, A. M., Zohairy, S. A., Momani, M. M., \& Wahby, M. H. (2014). Promoting awareness of teaching collocations techniqes to beginners (Adjective-Noun Collocations). European Scientific Journal, 10(10), 390-396.

Alsaleem, B. I. A. (2013). The effect of "Whatsapp" electronic dialogue journaling on improving writing vocabulary word choice and voice of EFL undergraduate Saudi students. Arab World English Journal, 4(3), 213-225.

Alsaleem, B. I. A. (2014). The effect of "WhatsApp" electronic dialogue journaling on improving writing vocabulary word choice and voice of EFL undergraduate Saudi students. In 21st Century Academic Forum Conference at Harvard. Boston: Harvard.

Anja, S. N., \& Ngwo, S. (2007). Information and communication technology as synergy for sourcing distance education: The feasibility in Cameroon education system. Educational Research and Reviews, 2(12), 296-301.

Anohina, A. (2005). Analysis of the terminology used in the field of virtual learning. Educational Technology \& Society, 8(3), 91-102.

Army, A. B. (2014). The impact of WhatsApp mobile social learning on the achievement and attitudes of female students compared with face to face learning the classrooms. European Scientific Journal, 10(22), 116-136.

Ashouri, S., Arjmandi, M., \& Rahimi, R. (2014). The impact of corpus-based collocation instruction on Iranian EFL learners' collocation learning. Universal Journal of Educational Research, 2(6), 470-479.

Bere, A. (2013). Using mobile instant messaging to leverage learner participation and transform pedagogy at a South African University of Technology. British Journal of Educational Technology, 44(4), 544-561. http://dx.doi.org/10.1111/bjet.12057

Bouhnik, D., \& Deshen, M. (2014). WhatsApp goes to school: Mobile instant messaging between teachers and students. Journal of Information Technology Education: Research, 13, 217-231.

Brown-Owens, A., Eason, M., \& Lader, A. (2003). What effect computer method communication, specifically instant messages, have on 8th grade writing competencies [Online source].

Calvo, R., Arbiol, A., \& Iglesias, A. (2014). Are all chats suitable for learning purposes? A study of the required characteristics. Procedia Computer Science, 27, 251-260. http://dx.doi.org/10.1016/j.procs.2014.02.028

Cavus, N., \& Ibrahim, D. (2009). m-Learning: An experiment in using SMS to support learning new English language words. British Journal of Educational Technology, 40(1), 78-91. http://dx.doi.org/10.1111/j.1467-8535.2007.00801.x

Chipunza, P. R. C. (2013). Using mobile devices to leverage student access to collaboratively-generated resources: A case of WhatsApp instant messaging at a South African University. In International Conference on Advanced Information and Communication Technology for Education ICAICTE. http://dx.doi.org/10.2991/icaicte.2013.66

Chou, S.-W., \& Liu, C.-H. (2005). Learning effectiveness in a Web-based virtual learning environment: a learner 
Ashiyan, Z., \& Salehi, H.

control perspective. Journal of Computer Assisted Learning, 21(1), 65-76. http://dx.doi.org/10.1111/j.1365-2729.2005.00114.x

Conole, G., De Laat, M., Dillon, T., \& Darby, J. (2008). Disruptive technologies, pedagogical innovation: What's new? Findings from an in-depth study of students' use and perception of technology. Computers \& Education, 50(2), 511-524. http://dx.doi.org/10.1016/j.compedu.2007.09.009

Crescente, M. L., \& Lee, D. (2011). Critical issues of m-learning: design models, adoption processes, and future trends. Journal of the Chinese Institute of Industrial Engineers, 28(2), 111-123. http://dx.doi.org/10.1080/10170669.2010.548856

Curtin, R. (2002). Promoting youth employment through information and communication technology (ICT): Best practice example in Asia and the Pacific. Bangkok.

Dearstyne, B. W. (2010). A new blueprint for success. Information Management Journal, 44(5), 42-46.

Derakhshan, A., \& Khodabakhshzadeh, H. (2011). Why CALL why not MALL: An in-depth review of text-message vocabulary learning. Theory and Practice in Language Studies, 1(9), 1150-1159. http://dx.doi.org/10.4304/tpls.1.9.1150-1159

Echeverría, A., Nussbaum, M., Calderón, J. F., Bravo, C., Infante, C., \& Vásquez, A. (2011). Face-to-face collaborative learning supported by mobile phones. Interactive Learning Environments, 19(4), 351-363. http://dx.doi.org/10.1080/10494820903232943

Grace, C. A. (1998). Retention of word meanings inferred from context and sentence-level translations: Implications for the design of beginning-level CALL software. The Modern Language Journal, 82(4), 533-544. http://dx.doi.org/10.1111/j.1540-4781.1998.tb05541.x

Helderman, R. S. (2003). Click by click, teens polish writing; instant messaging teaches more than TTYL and ROFL. The Washington Post, 20.

Hill, J. (1999). Collocational competence. In Readings in Methodology (pp. 162-166). Retrieved from https://btk.ppke.hu/uploads/articles/671983/file/Somogyi-Toth2006\%20Readings.pdf

Hindu, H. 2011. 'WhatsApp comes to the rescue. Features/education plus. Education plus Journal, 3, 23-26.

Hoey, M. (2004). The textual priming of lexis. In G. Aston, S. Bernardini, \& D. Stewart (Eds.), Corpora and Language Learners (pp. 229-246). London: Continuum. http://dx.doi.org/10.1075/scl.17.03hoe

Hyland, K. (2008). As can be seen: Lexical bundles and disciplinary variation. English for Specific Purposes, 27(1), 4-21. http://dx.doi.org/10.1016/j.esp.2007.06.001

Keegan, D. (2008). The impact of new technologies on distance learning students. E-Learning \& Education, 4 [Online]. Retrieved from https://eleed.campussource.de/archive/4/1422

Kim, Y. (2011). The role of task-induced involvement and learner proficiency in L2 vocabulary acquisition. Language Learning, 58(2), 285-325. http://dx.doi.org/10.1111/j.1467-9922.2008.00442.x

Krashen, S. (1989). We acquire vocabulary and spelling by reading: Additional evidence for the input hypothesis. The Modern Language Journal, 73(4), 440-464. http://dx.doi.org/10.1111/j.1540-4781.1989.tb05325.x

Laufer, B., \& Ravenhorst-Kalovski, G. C. (2010). Lexical threshold revisited: Lexical text coverage, learners' vocabulary size. Reading in a Foreign Language, 22(1), 15-30.

Leitch, S., \& Warren, M. (2015). Applying classification controls to Internet content in Australia. Journal of Information, Communication and Ethics in Society, 13(2), 82-97.

http://dx.doi.org/10.1108/JICES-08-2014-0037

Lenhart, A., Madden, M., Macgill, A., \& Smith A. (2007). Teens and social media. York Press.

Lenhart, A., Madden, M., Smith, A., \& Macgill, A. R. (2009). Teens and social media: An overview. Washington, DC: Pew Internet and American Life.

Lewis, M. (1997). Pedagogical implications of the lexical approach. In J. Coady \& T. Huckin (Eds.), Second language vocabulary acquisition: A rationale for pedagogy (pp. 255-270). Cambridge Press.

Lewis, M., \& Conzett, J. (2000). Teaching collocation: Further developments in the lexical approach. Language Teaching Publications Hove.

Lundin, J., Lymer, G., Holmquist, L. E., Brown, B., \& Rost, M. (2009). Integrating students' mobile technology in higher education. International Journal of Mobile Learning and Organisation, 4(1), 1-14. http://dx.doi.org/10.1504/IJMLO.2010.029951 
A comparison of male and female learners' English collocation learning through using WhatsApp

Mark, W. (1995). E-mail for English teaching. Washington DC: TESOL

Mason, Robi., \& Rennie, F. (2008). E-learning and social networking handbook. Resources for higher education. Abingdon, Oxon: Routledge.

Mazaji, B. (2015). Effects of digital games on vocabulary acquisition of Iranian low proficiency male and female EFL learners. International Journal of Foreign Language Teaching and Research, 3(10), 83-92.

McNeal, T., \& van't Hooft, M. (2006). Anywhere anytime: Using mobile phones for learning. The Journal of the Research Center for Educational Technology, 2(2). Retrieved form http://www.rcetj.org/index.php/rcetj/article/viewArticle/91

McNicol, D. (2005). A primer of signal detection theory. Psychology Press.

Milanovic, R. (2013). Building a better business website: 10 crucial strategies for turning your online presence into something your company can actually use. Randy Milanovic.

Milanovic, R. (2015). The World's 21 most important social media sites and Apps in 2015. Retrieved from http://www.socialmediatoday.com/social-networks/2015-04-13/worlds-21-most-important-social-media -sites-and-apps-2015

Ministry of Education Malaysia. (2003). Education Development plan: 2001-2010.

Mirsalari, G.-A., \& Shokouhi, H. (2010). Collocational knowledge versus general linguistic knowledge among Iranian EFL learners. The Electronic Journal for English as a Second Language, 13(4). Retrieved from http://www.tesl-ej.org/wordpress/issues/volume13/ej52/ej52a7/

Motallebzadeh, K., Beh-Afarin, R., \& Rad, S. D. (2011). The Effect of short message service on the retention of collocations among Iranian lower intermediate EFL learners. Theory and Practice in Language Studies, 1(11), 1514-1520. http://dx.doi.org/10.4304/tpls.1.11.1514-1520

Moura, A., \& Carvalho, A. A. (2010). Mobile learning: using SMS in educational contexts. In Key competencies in the knowledge society (pp. 281-291). Springer. http://dx.doi.org/10.1007/978-3-642-15378-5_27

Oh, E., \& French, R. (2004). Pre-service teachers' perceptions of an introductory instructional technology course. Electronic Journal for the Integration of Technology in Education, 3(1), 37-48.

Prensky, M., \& Berry, B. D. (2001). Do they really think differently. On the Horizon, 9(6), 1-9. http://dx.doi.org/10.1108/10748120110424843

Richards J. C., \& Schmidt, R. (2002). Longman dictionary of applied linguistics and language teaching. Harlow: Longman.

Salavati. (2016). Using instructional video games as an ICT tool for teaching English vocabularies to Iranian EFL learners. Islamic Najaf Abad University.

Salehi, H., \& Salehi, Z. (2012a). Challenges for using ICT in education: Teachers' insights. International Journal of E-Education, E-Business, E-Management and E-Learning, 2(1), 40-43.

Salehi, H., \& Salehi, Z. (2012b). Do high-stakes tests facilitate or hinder the use of ICT in the classroom? In $3 r d$ International Conference on e-Education, e-Business, e-Management and e-Learning. Singapore.

Salehi, H., \& Salehi, Z. (2012c). Integration of ICT in language teaching: Challenges and barriers. In Proceedings of the 3rd International Conference on e-Education, e-Business, e-Management and e-Learning (IC4E, 2012), IPEDR (Vol. 27, pp. 215-219).

Salehi, H., Shojaee, M., \& Sattar, S. (2014). Using e-learning and ICT courses in educational environment: A review. English Language Teaching, 8(1), 63-70. http://dx.doi.org/10.5539/elt.v8n1p63

Schulz-Zander, R., Büchter, A., \& Dalmer, R. (2002). The role of ICT as a promoter of students' cooperation. Journal of Computer Assisted Learning, 18(4), 438-448. http://dx.doi.org/10.1046/j.0266-4909.2002.002.x

Sinclair, J. (1991). Corpus, concordance, collocation. Oxford University Press.

Smith, C. (2005). The lexical approach: Collocation in high school English learners. George Fox University.

Solgi, F., \& Dara, T. (2014). Collocation learning through CALL: Comparing in-class and out-of-class instructions. International Journal of Instructional Technology and Distance Learning, 11(2), 31-42.

Stowe Jr, W. A. (2013). Comparison of learning performance between students who do and students who do not use mobile technology-based activities [Unpublished doctor dissertation]. University of North Texas.

Susilo, A. (2014). Exploring Facebook and Whatsapp as supporting social network applications for English 
learning in higher education. In Teaching and learning in the $21^{\text {st }}$ century: Challenges for lectures and teachers (pp. 10-24).

Sweeny, S. M. (2010). Writing for the instant messaging and text messaging generation: Using new literacies to support writing instruction. Journal of Adolescent \& Adult Literacy, 54(2), 121-130. http://dx.doi.org/10.1598/JAAL.54.2.4

Thornton, P., \& Houser, C. (2005). Using mobile phones in English education in Japan. Journal of ComputerAssisted Learning, 21, 217-228. http://dx.doi.org/10.1111/j.1365-2729.2005.00129.x

Traxler, J. (2007). Defining, discussing and evaluating mobile learning: The moving finger writes and having writ... The International Review of Research in Open and Distributed Learning, 8(2). Retrieved from http://www.irrodl.org/index.php/irrodl/article/view/346/875 http://dx.doi.org/10.19173/irrodl.v8i2.346

Trentin, G., \& Repetto, M. (2013). Using network and mobile technology to bridge formal and informal learning. Elsevier. http://dx.doi.org/10.1533/9781780633626

United Nations. (2013). Retrieved from http://www.un.org/apps/news/story.asp?NewsID=44452

Unwin, A. (2007). The professionalism of the higher education teacher: what's ICT got to do with it? Teaching in Higher Education, 12(3), 295-308. http://dx.doi.org/10.1080/13562510701278641

Westera, W., \& Sloep, P. B. (2001). The future of education in cyberspace. In L. R Vandervert, L. V. Shavinina \&. R. A. Cornell (Eds.), Cyber education: The future of distance learning (pp. 115-136). Larchmont, NY: Mary Ann Liebert.

Yahyaabadi, F. (2015). The impact of using social networks: Viber application on the complexity criterion in the 12 writing of intermediate male and female Iranian EFL learners (Unpublished master's thesis). Najaf Abad University.

Yeboah, J., \& Ewur, G. D. (2014). The impact of whatsApp messenger usage on students performance in Tertiary Institutions in Ghana. Journal of Education and Practice, 5(6), 157-164.

Young, S. S. C. (2003). Integrating ICT into second language education in a vocational high school. Journal of Computer Assisted Learning, 19(4), 447-461. http://dx.doi.org/10.1046/j.0266-4909.2003.00049.x

Yueng, K. (2013). Whatsapp processed a whopping (record) 18 billion messages on the last day of 2012. TNW News. Retrieved from http://www.thenextweb.com

Yunus, M. M., \& Salehi, H. (2012a). The effectiveness of Facebook groups on teaching and improving writing: Students' perceptions. Journal of Education and Information Technologies, 1(6), 87-96.

Yunus, M. M., \& Salehi, H. (2012b). Tumblr as a medium to improve students' writing skills. Journal of Applied Sciences Research, 8(1), 383-389.

Yunus, M. M., Nordin, N., Salehi, H., Embi, M. A., \& Mahamod, Z. (2013). Managing problems and planning activities involving ICT tools in teaching ESL reading and writing. Asian Social Science, 9(10), 222-230. http://dx.doi.org/10.5539/ass.v9n10p222

Yunus, M. M., Nordin, N., Salehi, H., Embi, M. A., \& Salehi, Z. (2013). The use of information and communication technology (ICT) in teaching ESL writing skills. English Language Teaching, 6(7), 1-8. http://dx.doi.org/10.5539/elt.v6n7p1

Yunus, M. M., Nordin, N., Salehi, H., Sun, C. H., \& Embi, M. A. (2013). Pros and cons of using ICT in teaching ESL reading and writing. International Education Studies, 6(7), 119-130. http://dx.doi.org/10.5539/ies.v6n7p119

Yunus, M. M., Salehi, H., \& Chenzi, C. (2012). Integrating social networking tools into ESL writing classroom: Strengths and weaknesses. English Language Teaching, 5(8), 42-48. http://dx.doi.org/10.5539/elt.v5n8p42 